Kaygl, 18(II)/2019: 391-417. Araştırma Makalesi | Research Article

Makale Geliş | Received: 30.05 .2019

Makale Kabul | Accepted: 10.08.2019

Yayın Tarihi | Publication Date: 30.09.2019

DOI: $10.20981 /$ kaygi.612790

\author{
Abdulhan ÜNLÜSOY \\ Dr. Öğr. Üyesi | Assist. Prof. Dr. \\ İnönü Üniversitesi, İlahiyat Fakültesi, Din Felsefesi Anabilim Dalı, Malatya, TR \\ İnönü University, Faculty of Theology, Department of Philosophy of Religion, Malatya, TR \\ ORCID: 0000-0001-6585-9340 \\ abdulhan.unlusoy@inonu.edu.tr
}

\title{
Felsefedeki Metodolojik Bir Yaklaşım Olarak Deneysel Felsefe Akımının Yargı Analizlerinin Epistemik Değeri
}

$\ddot{O} z$

Metafilozofik çalışmaların oldukça yoğun olduğu günümüz felsefesindeki en yeni ve heyecan verici akımlardan birisi de Deneysel Felsefe akımıdır. Deneysel Felsefe, kendisi dışındaki geleneksel felsefî metodolojiler olarak nitelediği metodolojilere şüphe ile yaklaşır. Bunların kullanmış oldukları kavram analizleri ve refleksiyon gibi metodolojilerin, felsefî birer spekülasyon olduklarını savunarak, bunların olgudan bağımsız iç gözlem ve informal diyaloglardan oluştuğunu savunur. Temel amacını, filozof olmayan sıradan insanların, felsefî tartışmalarda kullanılan kavramlarla olan ilgilerini araştırmak, onların bu kavramları ifadede kullandıkları felsefî yargılarını sistematik ve kontrollü bir şekilde incelemek olarak belirler. Ortak duyu ile uyumlu pozisyona sahip felsefî̀ iddiaları test ederek delillerle desteklenmeyenleri reddeder. Deneysel Felsefe, toplumsal yargıların kontrollü ve sistematik bir tarzda incelenebilmesi için deneysel psikoloji başta olmak üzere istatistik gibi felsefe dışı bilişsel bilim çalışmalarını ve pozitif bilimin yöntemlerini ödünç alır. Deneysel Felsefenin deneysel sıfatını kullanmadaki haklı nedeni, hem pozitif bilim yöntemlerini felsefî alana dâhil etme gayreti hem de bunu yaparken interdisipliner bir özellik taşımasıdır. Deneysel Felsefenin kendine sorduğu sorular şunlardır: Yargılarımız, felsefî problemlerin ele alınmasında güvenilir bir hareket noktası olarak alınabilir mi? Yargılarımızı meydana getiren bilişsel mekanizm türleri nelerdir? Bu mekanizm türleri, uygun felsefî araçlar olarak alınabilir mi? Hangi tür yargıların doğru olarak alınıp alınamayacağını nereden bileceğiz? Birbiriyle çatışan yargılardan doğru olanını tespit etmemize yarayacak ölçütlerimiz nelerdir? $\mathrm{Bu}$ ve buna benzer sorulara Deneysel Felsefe merkezli verilen cevaplar, bu makalenin konusunu oluşturur. Bu çalışmanın bir diğer amacı da, oldukça yeni olan bu felsefî metodolojiyi Türk okuruna kısmen de olsa tanıtmaktır.

Anahtar Kelimeler: Felsefe, Deneysel Felsefe, Metodoloji, Kavramsal Analiz, Felsefî Yargı.

\section{The Epistemic Value of Experimental Philosophy's Intuitional Analysis as A Methodological Approach in Philosophy}

\footnotetext{
Abstract

One of the most recent and exciting current in metaphilosophic which has quite profound works is experimental philosophy. Experimental philosophy suspects to the methodologies which it named as traditional philosophical methodologies except itself. It asserts that the methodologies like concept analysis and reflection are just like a philosophical speculation. It also defends that they are away from facts but they are constituted by introspection and informal dialogues. The main goal of the experimental philosophy is to research both nonphilosopher ordinary people's interest to the terms used in philosophical discussions and search their intuition and estimation in their expressions by using their terms in systematically and in a controlled way. It also has the aim of testing philosophic allegations which have common sense and suitable positions by refusing the ones which aren't supported by evidences. Experimental philosophy utilizes from non-philosophic hard science
} 
methodologies and studies like experimental psychology and statistics to be able to examine the common estimation in a controlled and systematic way. The reason why experimental philosophy use the term "experimental" is the effort of implicating in the methodologies of hard science to the philosophy by being interdisciplinary while doing this. The questions that experimental philosophy asks itself are these: Are our intuitions reliable enough for approaching the philosophical problems? What are the sorts of cognitive mechanism which give birth to our intuitions? Are those kinds of mechanism suitable enough for philosophical means? How do we know that whether what kind of intuitions are correct or not? What are our criterions for determining the correct intuitions jarring with each other? Experimental philosophy based answers to those questions consist of article's topic. Another aim of this study is to introduce new philosophical methodology to the Turkish readers.

Keywords: Philosophy, Experimental Philosophy, Methodology, Conceptual Analysis, Philosophical Intuitions.

\section{Giriş}

Her şeyden önce Deneysel Felsefe (Experimental Philosophy) teriminin standart ve üzerinde geniş bir felsefî çoğunluğun anlaştığı bir tanımı yoktur. Bu felsefe türü, genel felsefenin bir alt alanı olarak görülür. Deneysel Felsefe, felsefî problemlerin sistematik deneysel yöntemlerle aydınlatılması amacını taşıyan oldukça yeni bir felsefe türüdür. Deneysel Felsefe, 20 yy. sonlarında ortaya çıkan modern deneysel bilim çalışmalarından yararlanır. Deneysel Felsefenin kullandığı yöntemlerde, psikoloji alanındaki çalışmaların ağırlığı vardır. Kabaca Deneysel Felsefe, felsefî problemler alanında düşüncenin biyolojik temelini ortaya koyarak epistemolojik sorunları aydınlatmaya çalışan ve bunu yaparken de çalışmalarını amprik verilere dayandırma gayesinde olan felsefî bir eğilimi ifade eder. Son dönemde ortaya çıkmış yeni bir felsefe türü olarak deneysel felsefe alanı ülkemiz akademyasında henüz üzerinde herhangi bir çalışmanın yapılmadığı bir alandır. Deneysel Felsefe teriminin nasıl kullanılacağı yönünde, bu alandaki düşünürlerin oldukça farklı teklifleri vardır. Bu tekliflerin, geneli itibariyle, Deneysel Felsefe teriminin tanımından kaynaklı çok geniş gerilimlere ve oldukça belirsiz sınır durumlara gönderme yaptığı aşikârdır. Deneysel Felsefenin epistemik açıdan değerlendirilmesine geçmeden önce yapılması gereken ilk iş, bu felsefî metodolojiyi kronolojik bağlamı içinde ele alıp tanımlamaya çalışmak olacaktır. 


\section{Felsefî Bir Yöntem Olarak Deneysel Felsefenin Ortaya Çıkışı}

Öncelikle Deneysel Felsefe ile uğraşan bütün düşünürler, felsefî eğitim ve profesyonel ilgi alanları bakımından filozofturlar. Ancak, bu alandaki en iyi çalışmaların sahibi olanlar, felsefe alanında derin bilgi ve eğitimi olmayan kimselerdir (Stich ve Tobia 2016: 5). Bu kimselerin özel ilgi alanları, meselâ psikoloji gibi, felsefe dışı ihtisas alanlaridir.

Meseleye kronolojik açıdan bakıldığında, Deneysel Felsefenin, erken dönemde, İngiltere'deki filozoflar tarafından 1650'li yılların sonunda, ilk defa belirginleşmeye başladığı söylenebilir. Felsefedeki bu tür bir hareketin temel odak noktaları, Royal Society of England ile ilişkilendirilir. Bu bağlamda Deneysel Felsefe terimi, ilk defa, 1660’lı yıllarda, bu toplulukla ilişkili yazılan kitaplarda kullanılmaya başlanmıştır. Bu dönemde, bu topluluğun üyesi birçok düşünür, kendilerini, Deneysel Felsefenin bir savunucusu olarak tanımlamıştır. Bu hareketin etki alanlarına baktığımızda ilk etki alanının, İngiliz tıbbında olduğunu görürüz. Tıp alanı dışında, Deneysel Felsefenin, politik alanlar da dâhil birçok alandaki etkilerini gözlemlemek mümkündür. Özellikle bu hareketin, 18. yy. ortalarında Ahlâk Felsefesi alanındaki birçok gelişmeye katkıları olmuştur. Günümüzde ise insan davranışlarıyla direkt ilgisi olan zihin felsefesi alanında ve psikolojiye yakın alanlarda, Deneysel Felsefenin etkilerini bulmak mümkündür (Anstey ve Vanzo 2016: 88).

Deneysel Felsefe ile uğraşan filozoflar, kendilerini, felsefî bir nostaljinin sahibi olarak tanımlarlar. Amaçlarını, felsefenin genel kavramlarına veya felsefedeki genel vizyona ya da felsefenin geleneksel sorunlarına bir dönüş olarak ifade ederler. Deneysel Felsefenin hayalini kurduğu bu felsefî yaklaşım, aslında, "felsefe" teriminin kendisi kadar eskidir. Bu anlamda Deneysel Felsefe, genellikle, metodolojik doğalcılığın özü olarak kabul edilir (Fischer ve Collins 2015: 23). Deneysel Felsefe yapan filozoflar için gözlem ve deney, felsefî iddiaların temellendirilmesinde, antikitedekine benzer bir tarzda kullanılır. Bu hususta ampirik yöntemleri kullanan bilim adamlarıyla filozoflar arasında katı bir ayrım yapma söz konusu değildir (Anstey ve Vanzo 2016: 87). Aslına bakılırsa Deneysel Felsefe diye bilinen yeni ve heyecan verici bir alt alan olarak ortaya 
çıkan bu hareketin, tarihsel anlamda hiçbir örneği olmadığını söylemek doğru değildir. $\mathrm{Bu}$ hareketten önce de felsefeciler, doğa ve toplum bilimleri alanında geleneksel olarak araştırmalarını devam ettiriyorlardı. Bu anlamda felsefî ve ampirik araştırmalar alanındaki ayrım, nisbeten son zamanlarda yapılan bir ayrımdır (Plakias 2015).

Deneysel Felsefe, ilk hareket noktası olarak, felsefe ile diğer bilimlerin birbirinden ayrılmadığ 1 durumlardakine benzer bir durumdan hareket eder. Geçmişte felsefe, Deneysel Felsefe yapan filozoflara göre, bu alanların hepsinde birtakım sorular sorar ve cevaplar verirdi. Filozoflar, bu alanlarda, her şeyin birbiriyle uyumlu olduğu bütüncül sorular sorar ve bütüncül cevaplar bulmaya çalışırdı. Deneysel Felsefe, bu bütüncül soru ve cevapların olduğu geleneksel vizyona dönüşü amaçlar. Geçmişte olduğu gibi filozofların sorduğu sorular, insana dair sorular olmalıdır (Knobe ve Nichols 2008: 3). Bilgi temelli yapılan araştırmaların odak noktası olarak bilen insan merkeze alınır. İnsanın bilişsel süreçleri ve bu süreçlere etki eden faktörler mercek altına alınır.

Deneysel Felsefenin iki hususta geleneksel felsefeye dayandığını söylemek mümkündür. Bunlardan ilki, geneli itibariyle, insanlar tarafından kabul edilip onaylanan ya da kabul edilmeyip bazı gerekçelerle reddedilen şeyleri araştırma konusu yapmak. İkincisi ise, genel kabul görmüş ve topluma yerleşmiş olan inanç temelli gerçeklere tereddütle yaklaşarak meydan okumak (Sosa 2008: 231). Bu bağlamda Deneysel Felsefenin 3 önemli özelliğe sahip olduğu söylenilebilir. İlki, bu tür felsefe, filozoflar tarafindan yapılan teknik bir iştir. İkincisi, Deneysel Felsefe süreci, ampirik çalışmaları da içeren birtakım süreçlerle ilişkilidir. Üçüncüsü ise, böyle bir felsefî yaklaşım, insanların felsefî yargılarıyla ilgili temel felsefî iddiaları test etme amacı taşır (Plakias 2015). Bu bağlamda Deneysel Felsefe, metodolojik natüralizmin özü olarak kabul edilen ilkelerden hareket eder (Fischer ve Collins 2015: 4). Deneysel Felsefe, aslinda, felsefî bir gelenek anlamında bir felsefe türü olarak ele alınmamalıdır. Daha çok felsefî problemlerin ele alınmasında kullanılan bir metodoloji, felsefenin bir alt alanı olarak anlaşılmalıdır. Deneysel Felsefe, felsefenin geleneksel teorik problem ve sorunlarına karşı, deneysel metodolojilerle ilişkisi içindeki psikoloji ve bilişsel bilim çalışmalarını 
içerir. $\mathrm{Bu}$ anlamda o, disiplinlerarası bir özellik taşır. Kabaca Deneysel Felsefe, herhangi bir felsefî problem hakkındaki sıradan insanların bu konudaki yargılarına, konuyu nasıl anladıkları üzerine yoğunlaşarak, insanların bu problem hakkındaki düşünce deneyimlerine başvurur. Bunu yaparken problemin en iyi örneklerini içerdiği düşünülen birtakım suni senaryoları kullanır. Deneysel Felsefe, felsefî problemlerle ilgili birtakım senaryoların, araştırılan felsefî problemlerle ilgili en iyi örneklem olarak kabul edilebilecek bir grup insana, felsefî problem temelli yöneltilen sorular ve bu sorulara sözü edilen grubun verdiği cevaplar ya da tepkiler temelli ilerleyen bir süreçtir. Ve yine Deneysel Felsefe bu süreç sonunda elde edilen dataların ampirik veri olarak alınmasından, analizinden ve sonuç olarak bu felsefî problemin çözümünde işimize yarayacak yargılara ulaşılmaya çalışılmasından ibarettir. Bu süreç, kavram analizleri, bilgideki psikolojik ve bilişsel süreçler, toplumsal inançlardaki etkin arka plan yapıları vb. gibi birçok problemi de beraberinde getirir. Ayrıca, senaryoların uygulandığı grupların en iyi örneklem olup olmaması, yapılan işin anket çalışmalarından farkı, örneklemi oluşturan insanlar arasındaki kültürel, eğitimsel, sosyo-politik farklar vb. gibi birçok problemi de felsefî açıdan ele alıp inceler. Makalemizin ilerleyen bölümlerinde, özellikle yargıların analizinde, kavram analizinin avantaj ve dezavantajları incelenirken Deneysel Felsefe ve onun eleştirisi bağlamında bu hususlara değinileceğinden şimdilik bu kadarıla yetiniyoruz.

\section{Deneysel Felsefenin Metodolojik Açıdan Analizi}

Deneysel Felsefe, bilginin edinilmesini kolaylaştırmada ve yargısal olanın yaygınlaştırılmasında etkin olan bilişsel süreçlerdeki bilimsel bulguları dikkate alma hususunda, diğer felsefî geleneklerin metotlarını savunanlara karşı bir baskı oluşturmuştur. Buradan yola çıkarak Deneysel Felsefenin, düşünsel-kavramsal bir analiz, verilerin epistemolojik değerlendirilmesi ve psikolojik alana başvuru olduğu söylenebilir (Fischer ve Collins 2015: 21). Bu alanların sahibi olarak Deneysel Felsefenin sadece toplumsal yargılar alanında değil, mevcut felsefî teorileri test etmenin 
ötesinde, yeni teorilerin ve felsefî analizlerin ortaya çıkarılmasında son derece etkili olduğu görülür (Plakias 2015).

Deneysel Felsefe, aslında, Çağdaş Felsefedeki yargı (intuition) kavramının kötüye kullanımı veya kullanım şekline açık bir cevap olarak geliştirilmiştir. Aslında bu bir yanlış anlamadır. Şöyle ki; deneysel olarak iyi tanımlanmış hiçbir çalışma, Deneysel Felsefenin ilgili olduğu kadar yargılarla ilgili değildir. Bu çalışmalara daha yakından bakıldığında Deneysel Felsefe için daha genel ve kökensel bir hikâye ayırt edilebilir. O da şudur: Deneyimsel felsefe, felsefecilerin, açık ya da örtülü bir biçimde ampirik iddialarda bulunmalarından ve bu iddialarını ampirik delillerle destekleme isteklerinden doğmuştur (Sytsma 2017: 24).

Felsefedeki modern çalışmalar, yargı konusundaki yetersizliklerinden yola çıkılarak itham edilirler. Bilgi, sebeplilik ya da özgür irade gibi kavramların doğasını anlamak isteyen bir düşünürün yapması gereken ilk şey şudur: $\mathrm{Bu}$ fenomenlerin doğaları hakkındaki düşünüm öncesi ilksel yargıları ortaya koymak için dizayn edilmiş, bir dizi hayalî durumlar inşa etmekle işe başlamak. Bu düşünüm öncesi ilksel hayalî yargılar, daha sonra, önemli kanıt kaynakları olarak ele alınırlar. Deneyimsel Felsefenin kendisine ilke olarak ele aldığı bu temel yaklaşım, çok çeşitli ve farklı alanlarda kapsamlı bir şekilde uygulanagelmiştir (Knobe ve Nichols 2008: 3).

Bilindiği kadarıyla deneysel olmayan felsefelerde filozoflar, hiçbir zaman, bir kavramın analizini, diğer bir kavramın analizinin terminolojisiyle açıklama yoluna gitmemişlerdir. Bunun yerine buradaki amaç, genellikle, bir kavramın uygulamalarını etkileyen faktörlerin bir tanımını yapmak ve özellikle de bu tür tanımların altında yatan psikolojik süreçlerin bir tanımını sağlamaya çalışmak olmuştur. Deneysel Felsefenin bu konudaki önerisi ise şudur: Konuya, kişilerin yargılarının gerçek örüntülerini karakterize edebilme hassasiyeti açısından değil de bunun yerine, bu kavramlara yaklaşırken, kavramların açıklayıcı derinliğe ulaşabilme derecesi açısından ölçülerek değerlendirilmesi gerektiğidir (Knobe ve Nichols 2008: 5). Bu tür bir yaklaşım, bizi, felsefî yargılarımızın da ötesine geçerek yargılarımızın altında yatan epistemik yapıları tespit etmemize imkân verir. 
Genel anlamda bilgi teorileri açısından bilgiye üç farklı yoldan ulaşılabilir. Akı1, duyular ya da yargilar yoluyla (Karsl1 2017: 498). Deneysel Felsefe, bilgi alanında, felsefî yargının ampirik metodolojilerle ele alınıp analizi yolunu tutar. Deneysel Felsefe, yargılarımıza etki eden faktörlerin ve onların altında yatan psikolojik ve nörolojik mekanizmin araştırılmasını hedefler (Stich ve Tobia 2016: 5). Örnek olarak " $X$ "'in (X burada bilgi, adalet vs. olabilir) ne olduğunu merak ediyorsak, "X" hakkında yapılması gereken ilk şey şudur: "X”"in burada “adalet" kavramı olduğu varsayılırsa eğer, kesin ve belirli bir şekilde "adalet" kavramıyla ilgili olduğu varsayılan bir dizi olgusal durumun düşünülüp analiz edilmesi ile işe başlanmalıdır. $\mathrm{Bu}$ yüzden, "adalet" konusundaki yargılarımızın başlangıçtaki bu ilk dizisine dayanarak, sorgulamalarımıza ayrıntılı ve özenli bir cevap bulmaya çalışabiliriz. Yani şunu demek istiyoruz: Yargılarımızın başlangıçtaki bu ilk dizisine yönelik en iyi açıklamaya dair bir teori geliştirebiliriz (Nicoli 2016: 5). Bu yaklaşım şekli Deneysel Felsefenin felsefî problemlerin çözümüne yönelik teori inşa sürecinin en iyi açıklaması olarak alınabilir.

Deneysel Felsefe yapan filozoflar sorumluluk, eylemlerin kasıtlı doğası vb. gibi geleneksel olarak felsefî ilgilerle alakalı kısa öykülere, insanların verdiği yanıtlara veya düşünce deneylerine dayanırlar. Deneysel Felsefede amaçlar, çok çeşitlidir. Bazıları, düşünce deneyleri sonucunda ortaya çıkan kararların, ön yargılardan etkilendiğini veya demografik gruplara göre değişkenlik gösterdiğini göstermek isterler. Bazıları ise felsefî konularla ilgili yargılar veya toplumsal teorileri ya da konumları tanımlamayı isterler. Bütün bu yapılanlar, bu yargılara yol açan bilişsel süreçleri anlamak anlamına gelir. Deneysel Felsefeyi genişletmenin doğal yolu, bilim adamlarının ve filozofların felsefî yargılarını araştırıp analiz etmekden geçer. $\mathrm{Bu}$ görüş, bazı düşünürler tarafından eleştirilse de bu yaklaşımda belirli bilimsel kavramların ve belirli bir bilimsel biliş tarzının analiz edilmesi vardır (Machery 2016: 476). Hangi tür yargıların Deneysel Felsefe açısından dikkate alınması gerektiği konusu ise aşağıda ayrıca ele alınacaktır.

Deneysel Felsefenin iki belirgin temel özelliğinden bahsedilebilir. İlki, Deneysel Felsefenin, insanların lengüistik yargılarıyla bu lengüistik yargıların içerikleri üzerine yapılmış ampirik araştırmaların sonuçlarıyla birleştirme teşebbüsü olduğudur. Benzer 
bir şekilde Deneysel Felsefe, natüralistik felsefenin test edilmemiş genel prensiplerinin, deneysel temellerle, bu temellere bağlı gözlemler üzerine inşa edilmiş sistemlerle birleştirme gayretinden ortaya çıkmıştır. İkincisi, Deneysel Felsefe, spekülatif ve a priori refleksiyona yönelik benzer tutumların sahibi olarak geleneksel felsefe ile ortak tavır içerisindedir. Bu anlamıyla Deneysel Felsefe ile uğraşan filozoflar, uygun ve evrensel olarak paylaşılan bir yargı kavramı üzerine yapılan felsefî analizde, düzenli kanıtsal bir temel sağlayacak geleneksel olarak kabul edilmiş araştırmalar yapmaya çalışırlar (Anstey ve Vanzo 2016: 98).

Deneysel Felsefenin kökleri acaba nereye kadar götürülebilir? Analitik Felsefedeki felsefî yargılara standart bir pratik olarak başvurmanın yaygın önemi gözönüne alındığında, Deneysel Felsefenin kökleri Analitik Felsefeye kadar götürülebilir kanaatindeyiz. Bu bağlamda Analitik Felsefedeki durum ilk bakışta şöyledir: Analitik Felsefedeki standart felsefî pratiklerin uygulamasına göre felsefî iddiaların kabul edilmesinde veya onların reddedilmesinde, biz, delil olarak, bu alandaki felsefî yargılardan hareket ederiz. Analitik Felsefî̀ iddiaların ele alınmasında bir hareket noktası olarak felsefî yargıların, düşünce deneyiminin sorunlarının çözülmesinde bir delil olarak alınması son derece yaygındır. Buradan hareketle Deneysel Felsefenin köklerinin, Analitik Felsefe geleneğinde aranması gerektiği sonucuna varılabilir.

Felsefî yargıların analiz edilip değerlendirilmesinde, düşünce deneyimlerine ilaveten yargılarımızın bir kanıt türü olarak kullanılması, aslında, Analitik Felsefe geleneğinde standart bir uygulama şekli olarak kabul edilegelmiştir. Felsefî problemlerin çözümünde yargılara müracaat eden Deneysel Felsefe hareketi, yeni bir felsefî hareket olarak kısmen Analitik Felsefedeki bu uygulama kaynaklıdır denilebilir (Sytsma 2017: 26). Sonuç olarak Deneysel Felsefe açısından felsefî problemlerin ele alınmasında kavramsal analiz ve yargıların analizi önemli bir yer tutar. Dolayısıyla biz de öncelikle kavramsal analizin felsefî bir metodoloji olarak incelenmesinin faydalı olacağı kanaatindeyiz. 


\section{Kavramsal Analizin Felsefî Metodolojideki Yeri}

Genel olarak felsefî bir problemi ele alırken filozoflar, iki önemli metottan hareket ederler. Bunlardan ilki kavramsal analizdir. İkincisi ise refleksiyondur. Her ikisinde de ortak olan düşünce deneyimlerindeki birtakım olgudan kopuk izah türleri, Deneysel Felsefe pratisyenleri tarafından şiddetle eleştirilir. Bu açıdan ilk olarak kavramsal analiz yöntemi üzerinde biraz durulması gerekir.

20. yy. felsefesine etkili metodolojik katkı sunan yaklaşımlardan birisi de kavram analizi diye bilinen yaklaşımdır. Bu yaklaşımın kullandığı birçok önemli metot ve teknikler, felsefî açıdan önemli olan birçok kavramın kullanımı hakkında önemli etkilerin sahibi olmuştur. Bununla beraber bu yaklaşımın, birçok metafiziksel sorunun ortaya çıkışına sebep olduğu da söylenebilir. Bir kavramın analizi, kesin olarak ne anlama gelir? Kavramsal bir analizin doğru ya da yanlış olduğunu nasıl biliriz? Bu ve benzeri sorular, kavramsal analizin amaç ve metotları konusunda birçok araştırma ve soruşturmaya yol açmıştır (Knobe 2016: 37).

Genel olarak kavramlar, zihinsel temsiller olarak kabul edilirler. Felsefî anlamda kavramlarla ilgisi bakımından refleksiyon, temel felsefî bir metot olarak alınır. Refleksiyon, bizim, içgözlemsel hafızamıza bir giriş yolu olarak kabul edilir. Buradan çıkan sonuç şudur: Kavramlar, bizim düşünce yapılarımızın keşfedilmesinde temel bir role sahiptir. Fakat şunun da altı çizilmelidir ki sentaks (sözdizim) gibi, düşüncelerimizin yapısıyla ilgili birçok olguya, tek bir bilinç türünden hareketle erişim zordur. Burada söylenmek istenen şudur: Felsefî problemler alanında sadece kavramsal analizle yetinmek yetmez. Bunun yanında, zihinsel temsiller olarak alınan kavramları destekleyen bilişsel düzeyde başka şeylere de ihtiyaç vardır (Prinz 2008: 93).

Felsefecilerin felsefî problemleri ele alırken kullanmış oldukları kavramsal analiz metodu, ampirik açıdan, deneysel yönü olmayan bir gözlem metodunun kullanılmasından ibarettir. Bu anlamda filozoflar, daha ziyade, müdahale ve gözlem olmaksızın dışarıdan kavramsal analiz yaparlar. Şeyler üzerinde refleksiyonda bulunma olarak kavramsal analiz metodunun, şeyler hakkındaki yargılarımızı ortaya çıkaran kavramsal gerçekliğin doğrudan bir refleksiyonu, bir yansıması olduğu varsayılır (Prinz 
2008: 91). Deneysel Felsefe, felsefî problemleri ele almada kullanılan refleksiyon metoduna ve onun bir uzantısı olan kavramsal analize, olgudan kopukluklarını sebep göstererek karşı çıkmıştır. Deneysel Felsefeye göre aynı itiraz, bilim felsefesi için de geçerlidir.

Meseleye bu açıdan yaklaşıldığında, özellikle bilim felsefecilerinin kullandığı ve adına deneysel kavram çalışması dedikleri çalışmaların, gerçek kavramsal analizler oluşturmada yetersiz olduğu görülecektir. Aynı şekilde bu tür kavram analizleri, bilimsel kavram analizlerinin test edilmesi açısından da yetersizdirler. Bilim felsefesinde filozoflar, bilimsel kavramların rasyonel olarak yeniden yapılandırılmasının mantıksal ve epistemolojik ilkelere uygun bir şekilde " $X$ " (veya "X" ile ilgili olan bir çıkarsama şeması) hakkında bazı önermeler sunmayı içeren bilimsel kavramların rasyonel yeniden yapılandırılması ile meşgul olurlar. Bir kavramın, rasyonel olarak yeniden yapılandırılmasının, bu yapılandırmada etkin rolü olan bilim adamının gözden kaçırılarak ele alınması da ayrı bir problem konusudur (Machery 2016: 479). Dolayısıyla Deneysel Felsefe, bilgi alanında, bu bilginin hem sahibi hem çıkış yeri olarak insandaki yargılardan hareket etmenin uygunluğu kanaatindedir.

Deneysel Felsefedeki kavram analizi çalışmaları, diğer kavram analizi çalışmalarından derin bir şekilde farklılık arz eder. Deneysel Felsefe çalışmalarının birçoğu, aslında, bilişsel bilim çalışmalarıdır. Çünkü bu çalışmalar, bu çalışmalarda etkili olan terimlerin altında yatan bilişsel süreçleri incelemeye çalışır. Bu çalışmaları anlamlı hale getirmenin yolu, kavramsal analiz geleneğinden ziyade, bilişsel bilim geleneğinin geliştirdiği çerçevelere bakmak olacaktır (Knobe 2008: 37-39). Dolayısıyla Deneysel Felsefe çalışmaları, bilişsel süreçleri incelemede psikoloji ile yakın ilişki içindedir.

Deneysel Felsefe, kullanımda olan herhangi bir kavramın, belirli kategorilerin nasıl anlaşılması gerektiği konusundaki imkânlarla ilgilidir. Bu yüzden Deneysel Felsefe ile uğraşan filozoflar, zihinsel kategorilere yoğunlaşırlar. Deneysel Felsefe yapan filozofların ilk ilgi alanları, toplum/grup psikolojisidir diyebiliriz. Fakat burada bir ayrım yapmak önemlidir. Deneysel Felsefeci filozoflar, bunu yaparken, grup 
psikolojisini doğru olarak kabul etmezler. Bu durum, aslında, Deneysel Felsefe ile Deneysel Felsefe arasında yapılması gereken ayrımın da kaynağıdır. Deneysel Felsefenin sorduğu sorular daha spesifik ve derindir. Deneysel Felsefe, Deneysel Felsefenin ilgili olmadığ genel ve derin kavramlarla ilgilidir (Prinz 2008: 198). Bu anlamda Deneysel Felsefe, ampirikal felsefî araştırmaları da kapsayacak daha geniş ve genel kavramlar keşfetme peşindedir.

Son yıllardaki metafilozofik konulara artan bir ilginin varlığı, analitik geleneğe mensup birçok düşünürü yargılarımızın doğasına yönelik bir araştırmaya yöneltmiştir. Felsefi yargılar, düşünce deneyimi aracılı̆̆ıyla ve düşünce deneyimi boyunca ortaya konulur. Çünkü düşünce deneyimleri, yargılara yönelik temyizin kabul edildiği, yani yargılara başvurulan ve yargılarımızın tanımlanmasının oldukça kolay olduğu özel mahallerdir. "Bir masuma zevk için işkence etmenin yanlışlığı" veya "karenin beş kenara sahip olmasının imkânsızlı̆̆ı" gibi yargılar da sezgisel durumlar olarak değerlendirilir. Yine de bütün bunlardan hareketle felsefî̀ yargılarımızın ne olduğuna yönelik bir tanım verebileceğimiz düşünülebilir mi? Orası şüphelidir (Nicoli 2016: 7-8). Dolayısıyla aşağıdaki satırlarda, felsefî yargıların ne olduğu ve yargılarımızın epistemik değeri ortaya konmaya çalışılacaktır.

\section{Felsefî Yargının Epistemik Değeri}

\subsection{Deneysel Felsefeye Göre Yargı Nedir? Neyi İfade Eder?}

Deneysel Felsefe ile ilgili metinlerde, felsefî yargılarımızı ifade etmek için İngilizce'de “intuition” kavramı kullanılır. Intuition kavramı, ilgili metinlerde Türkçeye genellikle "sezgi" olarak çevrilir. Düşünce tarihinde bu kavramın tanımından, bilgi ile olan ilişkisine kadar çok fazla şey yazılıp çizilmiş ve söylenmiştir. Kısaca ele almamız gerekirse sezgi, felsefî anlamda, akıl ve akıl yürütmenin dışındaki bir olguya göndermede bulunur. $\mathrm{Bu}$ anlamda sezgi, hakikatin kendi bütünselliği içinde aniden kavranmasıdır. Sezgide, dolaysız ve aracısız bir kavrayış söz konusudur. Sezgi, olgular arasındaki ilişkilerin aracısız bir şekilde keşfedilmesidir. Sezgisel bilgide, bilginin, insan zihnine doğrudan verilmesi ve edinilen bilginin şüpheden uzak olma özelliği 
vardır. Dolayısıyla sezgisel bilginin doğruluğunu saptayacak dışsal bir argümantasyon yoktur. Doğruluğu apaçık olmakla birlikte, yanlışlığını gösterecek bir şey yoktur. Sezgisel bilgide tecrübe ve yaşayarak öğrenme; tasavvufî anlamda zevk sözkonusudur (Vural 2002: 179). Kısacası sezgisel bilginin nesnesi, burhanî olarak gösterilemez. Ancak bu tür bilgiye ulaşma yolları ve metodolojileri gösterilebilir. Sezgisel bilginin dışındaki akıl yürütmelerle elde edilen bilgilerde ise bilgilerimiz, kavramlarımıza dayanır. Kavramsal olarak edinilen bilgiler, eşyanın hakikatini göstermede yetersizdir. Bu tür bilgi, eşyanın hakikatini göstermeyip ancak ona delalet eder (Vural 2002: 180).

Özü itibariyle sezgisel bilgi, varlığı, varlığa aşkın bir bilgilenmeyle kavramaktır. Sezgi, hakikatin birdenbire herhangi bir kasıt olmaksızın kavranılmasıdır. Sezgi, belirli birtakım ilkelerden hareketle sonuçlara hızlı bir şekilde intikal etmeyi ifade eder. Sezginin anlamlarına baktığımızda anlamak, görmek, gözlemlemek, dikkatini vermek, dikkatlice bulmak, dolaysız kavramak, bir anda yakalamak gibi birbirinden farklı birçok anlamı bünyesinde barındırdığını görürüz. Bu anlamlardan hareketle sezgisel bilginin, belirli bir konuya sahip olduğu ve o konu hakkında hızlı ve aracısız bir bilgilenme yolu olduğu ortaya çıkar (Karslı 2017: 499). Felsefî anlamda sezgi kavramı ile ilgili bu açıklamalardan sonra düşünce tarihi boyunca hem Batıdaki hem de İslam düşünce geleneğindeki sezgi ve sezgisel bilgi ile alakalı merkezî görüşlere kısaca değinmekte fayda vardir.

Düşünce tarihinde sezginin, sezgisel bilginin rasyonel süreçler içinde vuku bulduğunu savunanlar vardır. Mesela İbn-i Sînâ sezgiyi, bilinenlerden bilinmeyene doğru hızlı bir geçiş olarak ifade eder (Haklı 2007:43) ${ }^{1}$. Bu bahsedilen hızlı geçişin olması için, kıyas yapan zihinde, kıyas işlemi sırasında, orta terimin aniden belirmesi gerekir. Dolayısıyla hiçbir öncül ve ilkeden hareket etmeksizin aniden sezgiyle bilmek, imkânsızdır. Böyle düşünen İbn-i Sînâ'da sezgi, rasyonel sürecin bir biçimi olarak yorumlanabilir (Karsl1 2017: 500).

\footnotetext{
${ }^{1}$ İbn Sînâ'nın sezgi teorisi hakkında ayrıntılı bilgi için bkz. GÜRSOY, Adnan (2015), İbn Sînâ'nın Sezgi Teorisi, (Yayınlanmamış Doktora Tezi, Ankara Üniversitesi Sosyal Bilimler Enstitüsü, Ankara).
} 
Descartes epistemolojisinde sezgi, kesin bilginin ilkeleri içine sinmiş bütünüyle aklın sınırları içinde olan, akıl üstü bir içeriğe sahiptir (Öktem 2000: 161-162). Descartesçı cogitoyu mümkün kılan şey, sezgidir. Bu anlamda ilk ilkelerin bilinmesi, sezgiyle mümkündür. Dolayısıyla Descartes'ın anladığı şekliyle sezgi, aklın dışına taşmayan psikolojik bir özelliğe sahiptir. Aklın kendisinin, yine bizzat kendisine dayanarak varlığı ve varlıkla ilgili bilgiyi, zorunlu önermelerin doğruluğu için tam güveni akılla ilişkisi içinde anlaşılabilecek sezgi sayesinde yakalayabilir. Bu anlamda Descartes'taki sezgi, bilgiyi üreten bir sezgi değil ama bilgiye güvenilirliğini veren bir şeydir. Sonuç olarak Descartes'taki sezginin, bilgide önsel bir işleve sahip olduğu söylenebilir (Karslı 2017: 502).

Bu konuda Heidegger de Descartes gibi düşünür. Heidegger'e göre bilgi, öncelikle sezgiseldir (Kurtar 2011: 2). Bilginin ilk başlangıcının sezgi olması, bilgi ve zamanın kendini yitimsellik olarak açması arasındaki bağlantıda temellenmektedir. Her ne durumda olursa olsun nesnelere ilişkin bilginin biçimini veren, nesnelerle doğrudan ilişkili olan ve düşüncenin de tüm içeriğini veren sezgidir (Kant 1993: 51). Anlama ve duyarlığın birbiriyle örtüş̧ebilmesi için sentez yetisine gereksinim vardır. Kant’a göre bu yeti imgelemdir. Ona göre en genel anlamıyla sentez, imgelem gücünün bir sonucu olmaktadır. İmgelem gücü, ruhun, kör ama ondan ayrılmaz olan bir işlevidir ve bu özelliğiyle bilinemez. Ancak bilincine varılabilir. İmgelem, anlama ve sezgiyi olanaklı kılan ortak köktür (Kurtar 2011: 14). Sezgi kavramının ve onun bilgi ile olan ilişkisinin düşünce tarihi boyunca yüklenen anlamını ifade ettikten sonra bu kavramın Deneysel Felsefe açısından neyi ifade ettiği konusuna geçebiliriz.

"Intiution" kavramı Deneysel Felsefe açısından bakıldığında birebir sezgi olarak değil de felsefî sezgilerimizi ifadede kullanılan felsefî yargı olarak dilimize çevrilebilir. Felsefî yargılarımız, Deneysel Felsefenin kullandığı anlamıyla, asıl ilgi alanı pratik felsefe olan John Bordley Rawls (1921-2002) tarafindan da kullanılip Deneysel Felsefenin bu kavrama yüklediği anlamlara uygun bir şekilde tanımlanmaya çalışılmıştır. Rawls, Platon ve Cephalus'un adalet kavramı etrafinda yapmış oldukları diyaloglardan yola çıkarak Platon'un kullanmış olduğu metottan hareketle olgu 
metodunu analiz ederek yargı kavramını belirlemeye çalışır. Rawls'a göre bu kavram, çeşitli durumlar karşısında söylememiz gereken şeyleri ifade eden kanılarımız/yargı ve hükümlerimiz, çıkarımlarımız için kullanılır (Rawls 1999: 30). Bu kavramın ilk hareket noktası Rawls'ın düşünsel denge (reflective eqilibrium) dediği düşünsel ilk düzeydir. Düşünsel denge kavramı, bir kavramın ya da olgunun belirlenmesi için hareket edilmesi gereken sıfır noktasını ifade eder. $\mathrm{Bu}$ düzey, her türlü sistematik epistemik önyargılardan ve kavram ya da olgunun tanımına etki edecek her türlü epistemik etkiden uzak olunan, bu etkinin sıfir olduğu bir düzeyi ifade eder. Rawls'a göre bu düzey, Sokratik problemler dediğimiz bir şeyin ne olduğu'na dair problemin çözümüne yönelik ortaya konan cevaplarda kullanılacak teorilerin inşa edilip, kavramın en iyi şekilde tanımlamasını gerçekleştirmek için kullanılacak her türlü kanı/hüküm/yargı'nın elde edilmeye çalışılması gereken düzeydir. Rawls'a göre bu bağlamda felsefî yargılar, hüküm verilecek olgularla ilgili gerekçelere yönelik yapılan bir araştırmanın sonucudur. Ve bu, bir olay ya da olgu durumu üzerinde birbirinden farklı şekillerde gerçekleşen yargılarımız üzerindeki mümkün etkilerin bir düşünümüdür. Daha açık bir şekilde ifade etmek gerekirse Rawls'a göre bir yarg1, açık bir şekilde teorik olmayıp teoriye dayanmadığında, yani teorik ilkelerin sistematik ve bilinçli bir uygulamasıyla belirlenmediğinde yargısal (intuitive) olur. Bunu formüle etmek gerekirse eğer, Rawls’a göre, bu, şu şekilde formüle edilebilir: Herhangi bir " $X$ " hakkında sahip olduğumuz bir yargı, "X" ile ilgili belirlenmiş herhangi bir teoriye başvuru yapmaksızın ya da kurgusal koşullarda " $\mathrm{X}$ " hakkında söylenilecek ya da söylenmesi gereken şeyleri ifade eder (Nicoli 2016: 5).

Tıpkı Rawls'ın yaptığı gibi psikolog ve filozofların naturalistik bir eğilimle sezgisel yargılara özel bir neden atfetme eğiliminde oldukları doğrudur. Buna göre bir yargı, herhangi bir başka inançtan bilinçli olarak çıkarılması mümkün olmayan bir inançtır. Gelenek odaklı fillozoflar ise daha içtenlikli cevaplar verirler. Örneğin bir yargının sahip olduğumuz bir tutum olduğu söylenir. Ya da yargılarımızın, sahip olduğumuz inançlar olduğu ifade edilir. Belki de onlar, bazı durumlarda belirli inançları bize çekici kılan eğilimlerdir. Yani bizi kabullenmeye kadar götürmeyip ancak bizi 
belirli önermeleri kabul etme yönünde hareket ettiren inançlar olarak tanımlanması mümkündür (Nicoli 2016: 58).

Yargılarımız ve onlarla ilgili yapılan bütün bu tanımlardan yola çıkan bazı Deneysel Felsefeci filozoflar, felsefî̀ teorileri test etme işinde felsefî yargıların rolünü, bilimsel teorileri test etmedeki gözlemin oynadığı role benzetmişlerdir. Buna karşı çıkan bazı düşünürler ise buna bir itiraz olarak olgularla ilgili hususlarda yargılarla ilgilenmenin retorik bir aygıttan başka bir şeyle ilgilenmek olmadığını ve retorikten başka bir şeye hizmet etmeyeceğini savunmuşlardır. Fakat kesin olan şudur ki, felsefî yargılarla ilgilenmek, bazı temel felsefi problemlerin ele alınıp incelenmesinde son derece önemlidir. Benzer şekilde yargılar, anlamla ilgili tartışmalarda hüküm vermek ve bu yüzden bir kelimenin ne anlama geldiği veya o kelimenin doğruluk koşullarının ne olduğuyla ilgili iddiaları kanıtlamak veya reddetmek için kullanılabilir. Felsefî yargıların bu yönlerine ek olarak filozoflar, bazen, daha genel ilkelerin yargısallığıyla ilgilenirler (Plakias 2015). Felsefî metodoloji açısından felsefî yargılar, felsefedeki genel ilkelerin tespiti açısından önemlidir.

\subsection{Kavramsal Analizde Felsefî Yargılara Başvurmanın Epistemik Değeri}

Deneysel Felsefede yargı kavramının ne ifade edip ne ile ilişkili olduğunu belirledikten sonra bu kavramın, kavram analizindeki öneminin ne olduğuna geçebiliriz. İster bireysel ister sosyal olsun kesin olan şudur ki, bütün kavramlarımızla şeyler arasında var olan bir boşluk vardır. İnsan zihninin işleyişi göz önüne alındığında, zihni oluşturan dilsel bölümlerin birisinin de sözdizim ile ilgili olduğu kabul edilir. Zihnin bu bölümü, kavramların söz dizimsel yönünden hareket edip tek tek bütün kavramlarla uğraşmak yerine, bu kavramların kurallı sözdizimini yöneten ilkelerden hareket eder. Burada kavramlarımızın bizzat kendisinden ve kavramlarımız arasındaki ilişkilerden hareket etme durumu vardır. Tıpkı bunun gibi felsefî̀ yargılarımızın da kavramlarımızın bizzat kendileriyle ilişkili olduğunu görmek mümkündür. Buradan hareketle denilebilir ki, zihnimizde, tıpkı sentaksla ilgili bir bölümün olması gibi yargılarımızla ilgili bir bölüm de vardır. $\mathrm{Bu}$ bölümün özelliği, tek tek bireysel yargılarımızla değil 
genelleştirilebilir kurallı bir yargılar bütünüyle ilgili olmasıdır. Dolayısıyla Deneysel Felsefeye göre zihindeki böyle bir yargısal bölümün tespiti ve analizi, yargılarımız ve kavramlarımız arasındaki epistemolojik ilgiler açısından son derece önemlidir. Fakat böyle bir zihnî kavrayış modeli, bilginin durumsal yönüyle buluşsal bir ilişki içinde olduğu için eleştirilmiştir (Kornblith 2015: 156-157). Bilgimiz, bu anlamda durumsal, ansal ve fragmentaldir. Bilgiye dair zihnî bir kavrayış ya da arayış merkezinde buluşsal bir tavır takınmak, bu anlamda, bilginin, olgudan bağımsız, sadece kavram düzeyinde ele alınmasını gerektirir. Böyle bir anlayış ise bilginin bütünselliği açısından eleştirilmiştir. $\mathrm{Bu}$ tür modelin epistemolojik metodolojiler açısından eleştirildiği noktalardan birisi de Deneysel Felsefenin birinci elden eleştirdiği masabaşı yöntemlerin yaygınlaşmasıdır. Bu tür filozoflara göre eğer gerçek bilgi peşindeysek, yargıların ötesine geçip dünya ile ilgilenmek gerekir (Kornblith 2015: 158). Yukarıda yapılan bu iki eleştiri, yargılarımızın kavramlarımızla olan ilişskileri açısından yapılan bütün eleştirilerin temel noktası olarak alınabilir.

Bu bağlamda bu eleştirilere şöyle yanıt vermek mümkündür: Deneysel Felsefe ile uğraşan filozoflar, " $X$ " hakkındaki teorileri genellikle "X"in algılanmasının salt kayıtları olarak görmeyi reddetmişlerdir. Dahası, söylediğimiz ya da düşündüğümüz şeyleri tanımlamak, filozofların şimdiye kadar çoğunun yaptığı bir şeydir. Şimdiye kadarki filozofların pek çoğunun belki de tümünün felsefî teorileri, yargılarımızın bir düzeltilmesinden ibarettir. Bu bağlamda denilebilir ki felsefî teoriler, aslında normlardır. Ne söylediğimize yönelik şeylerin bir tanımlaması değildir. Dahası bu normlara yol açan yapısal ve hüküm koyucu süreçte, düşünme deneyimleri yoluyla elde edilen yargılarımıza başvurudan daha fazlası vardır (Nicoli 2016: 152). Dolayısıyla yargılarımızın olgudan bağımsız olarak alınması diye bir şeyin söz konusu olmaması gerekir. Çünkü yargılarımız, kavramlarımızın inşa edilme sürecindeki olgusal içerikler de dâhil birçok diğer faktörü bünyesinde barındıran üretme kaynakları olarak alınmalıdır.

Geleneksel bakış açısına göre felsefî yargılar, kavramlarımızla yakın ilişkilere sahiptir. Özellikle uygun şekilde anlaşılan yargılar, kavramlarımızın içeriğine epistemik 
erişim sağlamaktadır. Biz, her ne zaman bilgi, iyi, kötü vb. gibi hipotetik, tümdengelimsel olguları ele alsak da bunlar hakkındaki çeşitli yargılara da sahip olduğumuzu görürüz. Dolayısıyla bütün bunlar yapılırken, hiç kimse, bu tür yargıların güvenilmez olduğunu düşünmez. Yargılar, felsefî düşünme işinde, verilerin tespiti konusunda güvenilir bir yol olarak önemli bir role sahipse güvenilir olmalıdır. Felsefî teorilerin inşasını kavramsal analiz olarak görenler, yargılarımızı, bu kavramlarımızın içeriğinin güvenilir göstergeleri olarak kabul etmelidirler (Kornblith 2015: 151).

Deneysel Felsefenin anladığı anlamda yargılarımızın bir sınıflaması işine girmeden önce şunun altı çizilmelidir: Felsefî anlamda, yargılarımızın her türlü deneysel kullanımında, Deneysel Felsefenin rolünü görmek mümkündür. Çünkü kabul edilmelidir ki, Deneysel Felsefe, yargılarımızın bütün biçimleri için uygun izleme ve test etme araçlarına sahiptir. Dolayısıyla yargılarımızın bir sınıflamaya tabi tutularak sahip olduğumuz yargılarımız arasındaki kategorik ayrımlara dikkat çekilmesi önemlidir. Yargı biçimlerini şu şekilde sınıflama yoluna gidebiliriz: Yargılarımızın birinci kısmı normatif teorileri test etmede kullanılan yargılarımızdır. İkinci kısmı belirli bir kavramın, belirli bir olgunun ya da olgu grubunun örneği olup olmadığına ilişkin yargılarımızdır. Üçüncü kısmı bir kavramın doğru bir şekilde kullanılıp kullanılmadığına ilişkin yargılarımızdır. Ve sonuncu kısmı da herhangi bir söylem ya da bu söylemle ilgili pratiğin özellikleri hakkındaki yargılarımızdır (Plakias 2015).

Yargılarımız hakkında böyle bir sınıflamayı yaptıktan sonra yargılarımızın, Deneysel Felsefe açısından yapılan analizlerine geçebiliriz. Deneysel Felsefe açısından yargılarımızın analizinde 3 aşama vardır. Bu aşamalar a) Deneysel analiz (experimental analysis), b) Deneysel betimleme (experimental descriptivism) ve c) Deneysel inşa (experimental restrictionism) aşamasıdır. Şimdi bu 3 aşamanın detaylandırılmasını yapabiliriz.

Deneysel analizin amacı, sıradan insanların felsefî tartışmalarla ilgililerini araştırmak ve onları ifade etme eğilimindeki yargılarını sistematik ve kontrollü bir şekilde araştırmaktır. Bu yüzden Deneysel analiz, ortak duyu ile uyumlu pozisyona sahip felsefî iddiaları test etme ve delillerle desteklenmeyen iddiaların da reddedilmesi 
amacını taşır. Bu görüşe göre gündelik inanç ve pratiklere uygun ve uyumlu sayılan felsefî̀ teoriler ele alınıp incelenir. Deneysel analizin temel görüşü, geleneksel metodik yaklaşımlara şüphe ile bakmaktır. Geleneksel felsefenin, felsefî spekülasyon, olgudan bağımsız içgözlem ve informal diyalog gibi metotları kullanmasına karşılık Deneysel analiz, toplumun yargılarının kontrollü ve sistematik bir tarzda incelenebilmesi için deneysel psikolojinin yöntemlerini ödünç alır ve kullanır (Nadelhoffer ve Nahmias 2007: 126).

Deneysel Felsefenin bu aşamadaki temel görüşleri şu olmalıdır: Deneysel analiz aşamasındaki filozofların, kendilerini, sadece toplumsal yargılarla ve bu yargıların felsefî bir sorun olarak ele alınmasıyla sınırlamaları gerekir. $\mathrm{Bu}$ filozoflar, aynı zamanda, bu tür yargıların kaynaklarıyla da ilgilenmelidirler. $\mathrm{Bu}$ bağlamda şu tür soruların cevaplanması önemlidir: Belirli tür olgular hakkındaki insanların sahip olduğu yargıları meydana getiren bilişsel mekanizm türleri nelerdir? Ve bu mekanizm türlerini uygun araçlar olarak alabilir miyiz? Hangi tür yargıların doğru olarak kabul edilebileceğini nasıl bileceğiz? Özellikle de farklı bireyler arasındaki ve farklı bireylere ait çatışan yargıların doğru olanını nasıl bileceğiz?

Çatışan yargıları yöneten farklı bilişsel mekanizmlerin nasıl anlaşılacağı ve devam eden bazı felsefî tartışmaların en iyi şekilde nasıl ele alınacağı konusunda ikinci aşama devreye girer. $\mathrm{Bu}$ aşama, deneysel betim (experimental descriptivism) aşamasıdır. Deneysel betim aşamasına göre sadece toplumsal yargıların aktüelliğinin araştırılması yetmez. Aynı zamanda bu yargıların nasıl meydana getirildiğinin belirlenmeye çalışılması da önemlidir. Deneysel betimin insan psikolojisini araştırması, insanlar tarafından ifade edilen yargıların etkilediği senaryoların çeşitli manipülasyonlarının test edilmesi yoluyladır. Bu sürecin bir amacı da yargılarımızı meydana getiren bilişsel süreçler ve bu süreçlerin mantıksal doğasını en iyi şekilde anlamaktır. Daha sonra bu araştırmaların felsefi sorunlarla ilgisinin araştırılması gerekir. Fakat Deneysel betim, bu bilişsel süreçler ve bu süreçlerin mekanizmiyle ilgilenmez. Daha çok felsefedeki ilk elden felsefî teorileri destekleyen zihinsel işlemlerin nasıl olduğuyla ilgili elde edilen verilerle ilgilenir. Yönelimsel edimler, özgür irade vb. kavramsal analizlerin temelleri 
gibi toplumsal yargılarla ilgili verileri kullanır. Deneysel betim, deneysel analizin meselâ zihnin nasıl çalıştığı hakkında bilgi sahibi olmamızı sağlayan çalışmalarıyla karşılaştırıldığında, bu tip çalışmalara hiç benzemeyen belirli felsefî teorileri göstermede kullanılan delilleri kullanır (Nadelhoffer ve Nahmias 2007: 127).

Son aşama Deneysel inşa (experimental restrictionism) aşamasıdır. Bu aşama, felsefede, yargıların kullanılıp kullanılmaması konusundaki ampirik mücadele olarak görülebilir. Deneysel inşanın temel amacı hem toplumsal yargıların uygunsuzluğunun ve çeşitliliğinin her ikisinin de ilgili olduğu ampirik delillerin biriktirilmesi yoluyla gösterilmesi hem de bu uygunsuzluk ve çeşitliliğin iyileştirilerek bunların analitik geleneğin sahip olduğu metot ve tekniklerle analiz edilmesidir. Eğer Deneysel inşa aşaması olmasayd1, sosyoekonomik ve kültürden kültüre değişen belirli konular hakkındaki yargılarımızın ve değişik felsefî̀ soruların ele alınıp bunlardan hareketle birtakım felsefi teorilerin inşası mümkün olmayacaktı (Nadelhoffer ve Nahmias 2007: 128).

\subsection{Deneysel Felsefe Açısından Yargı Analizinin Önemi}

Deneysel Felsefe açısından felsefî problemlerin çözümünde yargılara başvurmak ve yargıların deneysel olarak analizi son derece önemlidir. Deneysel Felsefe açısından yargılarımızın epistemik özelliklerine geçmeden önce felsefî problemleri çözmede yargılara başvurunun önemi hakkında birkaç cümle kurmamız gerekir.

Deneysel filozoflara göre felsefe, kişinin cinsiyetine, sosyal statüsüne, eğitimine vb. art alan yapılarının kaynağı olarak alınabilecek yargılarına bağlı inşa edilen ya da bunlara uygun teorilerle gerçekleştirilen rölativistik bir yorumdur. Deneysel Felsefeye göre eğer normatif bir kural, yargısal olarak kabul edilemez bir sonuca bizi götürüyorsa, bu sonucun dayanağı olan o yargı düzeltilmelidir. Eğer bir çıkarım, bizim, yargısal olarak düzeltilmeyi istemediğimiz bir normatif kuralı ihlal ediyorsa o zaman yargımız değil normatif kuralın kendisi reddedilir (Weinberg vd. 2008: 20). Deneysel Felsefe açısından felsefî problemlerin çözümünde yargıları dayanak noktası olarak almanın 
anlamı budur. Deneysel Felsefeye göre felsefî problemleri ele almadaki tavrımız şu olmalıdır: Felsefî problemler çözülürken düşünme deneyimi esnasında terk edilmesi gereken şeyler, felsefî̀ düşünceyi temel olarak destekleyen yargılar değil geleneksel felsefî aktivite tarzının kendisidir. Diğer bir deyişle, çöpe atılması gereken sadece felsefî gelişim sonucu elde edilen sonuçlar değil bugüne kadar yürürlükte olan felsefî yorumların kendisidir. Bu yüzden buradaki soru, felsefenin nasıl düşünülmesi gerektiği ile ilgilidir. Daha da önemlisi Deneysel Felsefenin bu yaklaşımından hareketle açığa çıkardığı temel soru şudur: Felsefe, başka türlü de düşünülebilir mi? Her ne kadar deneysel filozoflar büyük ölçüde yargılara dayanan, yargıları temele alan bir metodolojinin taraftarı olsalar da bu revizyonun neleri içermesi gerektiği hususunda kesin bir belirlenim ortaya koyamamışlardır. Acaba yargılara başvuruyu sadece bazı yargılarla sınırlamalı mıyız? Meşru olarak bizim başvuracağımız yargılar hangileridir? Diğer gruplara nazaran belirli bir grup lehine verilen kararlar, o grubun yargılarını öne çıkarma noktasında bünyesinde keyfilikleri barındırır mı? Böylesi yargılara başvurudan tamamen vaz mı geçeceğiz? Değilse alternatiflerimiz nelerdir? Bütün bu soruların cevabı Deneysel felsefeci filozofların metinlerinde cevabı olmayan sorulardır (Nicoli 2016: 130). Filozofların yargıları ve felsefî metodolojilerin temelde güvenilirliği bu problemlerin çözümüne bağlıdır. İlk olarak bu sorunun cevabı, sahip olduğumuz felsefe algısına bağlıdır. Yani felsefî araştırmanın amaçlarının ve sonuçlarının ne söylememiz gerektiğinin açıklaması olarak kabul edilmesi mi yoksa sahip olduğumuz yargılar açısından normatif olarak mı anlaşılması gerektiği hususuna bağlıdır. İkincisi bu sorunun cevab1, felsefî metodolojilerin bu problemin çözümüne yönelik vermiş olduğu açıklamalara bağlıdır. Üçüncüsü ve en önemlisi de yargıların ampirik hipotezler olarak kabul edilmesi gerekip gerekmeyeceğine bağlıdır (Nicoli 2016: 151). Ancak filozofların sadece aktüel felsefî metodolojilerin gözden geçirilmesi lehine genel uyarlamalar yapmaları, doğru değildir. Aksine onlar, olgudan bağımsız icra edilen masabaşı felsefelerinin yerine bir alternatif metodoloji kurmayı hedeflemelidirler. Onlar, bize, pratikte ampirik metodolojiyle birlikte bizzat deneysel felsefenin inşasına çalışarak bizim ihtiyacımız olan alternatifleri sunmaya çalışmalıdırlar (Nicoli 2016: 130). 
Yeri gelmişken felsefî düşünümde filozofların yargılarını ayrıcalıklı bir konumda görmeye şüphe ile yaklaşan düşünürlerin temel gerekçelerine de değinilmesi gerekir. Şöyle ki, açık ve genel bir şekilde anlaşıldığı kadarıyla filozofların ortaya koyduğu yargıların doğru olarak kabul edilmesi, insan toplumundaki son derece sınırlı bir grubun düşünce yolunu/konuşma biçimini kabul etme anlamına gelir. Yargıların felsefî açıdan birbirleriyle ilgisiz faktörler serisine (kültür, cinsiyet, sosyoekonomik statü/durum, olguyu değerlendirenin eğitim düzeyi vb.) bağlı olarak değişiklikler göstermesi de mümkündür. Dahası buna ilaveten yargılar, temsil edilen olgu deneyinde, deneyin karakteristiklerine göre de değişir (Nicoli 2016: 119). Dolayısıyla yargılarımıza etki eden bu kadar fazla etkenin yanında belirli bir zümrenin ayrıcalıklı olması düşünülemez.

Büyük ölçüde yargı analizine dayanan bir felsefî yöntem, filozofların istediği türden sonuçlara bizi götürmeye elverişli olmalıdır. Buradaki sorun, en nihayetinde, amaçların doğası ile felsefî araştırmaların sonuçlarının ve fillozofların ilgilenmiş olduğu delillerin doğası arasındaki uyum problemidir. "X"'in gerçekte ne olduğunu kurmayı amaçlayan teorilerin inşa edilmesinde, meşrulaştırılmasında ve eleştirilip kritize edilmesinde yargılarımız neden ve nasıl önemlidir? (Nicoli 2016: 113). Felsefî yargılar, filozofların kendi yetkinlikleri ışığında ve refleksiyon kapasitelerine bağlı olarak gerçekleşen düşünümleri neticesinde söylediklerinin doğru olduğunun bir ifadesidir. Buradaki önemli olan husus, felsefî̀ yargıların teori inşa etme ve bu teorinin gerekçelendirilme sürecindeki rollerini meşru bir şekilde yerine getirmelerini sağlayan, hemen belli olmayan normatif bir yöne sahip olmalarıdır. $\mathrm{Bu}$ argüman, deneysel filozofların geleneksel felsefe metodolojilerine yönelik eleştirilerine karşı koymada oldukça kullanışlıdır (Nicoli 2016: 114).

Yargılarımız hususunda bu belirlenimleri yaptıktan sonra şimdi de yargılarımızın epistemik açıdan değerlendirilmesine geçebiliriz. Epistemik bir yargı, her şeyden önce ait olduğu alanın özel durumlarına uygun epistemik özelliklerle ilgili olan ve kendiliğindenliğe sahip bir yargıdır. Yani bu tür yargılar, yargılamayı yapan kişinin makul bir gerekçelendirme sunamayacağı, sebepsel açıklamaların uzağındaki bir durumdur. Epistemik normları keşfetmek için yargıya dayalı romantik bir stratejiyi, şu 3 
şartın yerine getirilmesiyle gerçekleştirebilirz: İlk olarak böyle bir strateji, veri veya girdi olarak epistemik yargılara dayanmalıdır. Ancak bu stratejinin başka türden çeşitli verileri de kullanmasında sakınca yoktur. İkincisi böyle bir stratejinin sonunda elde edilen epistemik konularla ilgili çıktılar, açık ya da örtük olarak normatif iddia ya da ilkeler üretmelidir. Normatif iddialar, aslında, düzenleyici iddialar olarak belirli bir konuda belirli bir kişiye ait inançların oluşumunda nasıl başlanılması gerektiğine dair düzenleyici iddialardır. Normatif iddialar, değersel yönü ağır basan iddialardır. Bu tür iddiaların bir diğer özelliği de inanç oluşumları için çeşitli stratejiler ve çeşitli epistemik durumların yararları hakkındaki değerlendirme iddiaları olmalarıdır. Sonuç olarak normatif iddialar, bir veya daha fazla inanç formasyonunun haklı inançlara ya da gerçek bir bilgiye dayalı iddialara yol açtı̆g 1 iddialardır. Normatif iddialar, belirli bir türden doktrinsel bir yapının gerçek bir bilgiye ulaştığı ya da böyle bir sonuca yönelik iddiaları içerir. Üçüncüsü ise bu tür stratejilerin çıktısı, kısmen girdi olarak aldığı epistemik yargılara dayanmalıdır. Eğer girdi olarak önemli ölçüde farklı yargılar varsa, bu strateji önemli ölçüde farklı çıktılar üretebilir (Weinberg vd. 2008: 20).

Yakından incelendiğinde görülecektir ki Deneysel Felsefeyle uğraşan filozofların, düşünce deneyimleri sonunda ifade ettikleri yargılar, insanların, olgular karşısında nasıl tepki verecekleri konusunda ampirik hipotezler olarak (bir kavram ya da onun kullanımına başvurma, ahlâkî bir senaryoyu yorumlama vb. gibi) alınabilir. Bu nedenle yargılar, ampirik olarak test edilebilirler (Nicoli 2016: 115). Bu söylenilenler Deneysel Felsefe çalışmalarının ampirik açıdan meşrulaştırılmasındaki haklı sebepler olarak alınabilir.

\section{Sonuç}

Deneysel metot, felsefede, dil felsefesi, etik, estetik, epistemoloji gibi birçok alanda başarılı bir şekilde uygulanmıştır. Fakat deneysel yöntemin en erken ve en kapsamlı savunucusu olarak kabul edilen bilim felsefesi, büyük ölçüde geçerliliğini günümüze kadar korumayı başarmıştır. Bilim felsefesindeki birçok sorunu ele almada bilim felsefesiyle uğraşan düşünürler, deneysel açıdan etkili olmayı başaramamışlardır. 
Ancak bu düşünürlerin deneysel ve daha genel anlamda ampirik metotları kullanmada, başkalarına hitap ederken kullandıkları yöntemler de dâhil olmak üzere, felsefedeki bazı temel meseleleri ele almada deneysel açıdan daha şüpheli değere sahip metotları kullanmaları, son derece talihsiz bir durumdur. Şöyle ki, bilim felsefesi, meselâ kavram analizi gibi metotlarda olduğu gibi olgudan kopuk masabaşı metotlar olarak bilinen refleksiyonlara/akıl yürütmelere başvurur. Bunun dışında bilim felsefesinin ortaya koyduğu genellemelerin, genellemeye dâhil üyelerin hepsini kapsayıcılığı da eleştirilen bir başka husustur. Deneysel Felsefe, bilim felsefesinin birçok yönden eleştirdiği bu ve benzeri hususları gözden geçirerek bu eleştirilere karşı savunmada birçok enstrümanlara sahiptir. Bu anlamda Deneysel Felsefe ile uğraşan filozofların metodolojik anlamda hem bilim felsefecilerinden hem de geleneksel metodolojiyi benimseyen felsefecilerden devşirip temellük edeceği birçok unsur vardır (Machery 2016: 475).

Felsefenin nev-i şahsına münhasır bir kavramsal analiz/inceleme olduğu kabul edilir. Meselâ Analitik Felsefeye mensup düşünürlere göre kavramsal kurallarla toplumsal uylaşımlar arasında bir ilişki vardır. Bu düşünürler, kavramsal kurallardan hareketle toplumsal uylaşımların ortaya çıkarılabileceğini savunurlar. Onlara göre genel yasa şudur: Aynı dili konuşan ya da belirli bir tarihsel zamanda ortaya çıkan aynı kültürü paylaşan bütün insanlar kavramsal bir art alana sahiptir (Gasparatou 2010: 3132). Wittgensteincı bir terminoloji ile konuşacak olursak, bütün insanlar, belirli yaşam formları tarafından sahip olunan kendisinden kaçmaları mümkün olmayan yargılar tarafından yönetilirler. Sahip olduğumuz bu yargılar da toplumsal uylaşım temelli kavramsal kurallar (gramer) ya da art alan kesinlikleri (sağduyular) tarafından yönetilirler. Sonuç olarak bahsi geçen bu belirlenimler sayesinde biz, epistemik standartlar adını verebileceğimiz birtakım standartların sahibi oluruz. Ancak epistemik standartlarımız üzerindeki bu etkileri tespit etmek zordur. Çünkü onlar, normatif olmadıkları gibi bilimsel olarak tespit edilmenin de uzağındadırlar. Durum her ne kadar böyle olsa da yargılarımız bir disiplin olarak felsefî otonomi ortaya koyarak otoritenin özel bir türünü ortaya koymanın yolunu açar. Aynı zamanda o, felsefecilerin kullanmak zorunda olduğu metotların ne olması gerektiğini de formüle eder. Şurası kesindir ki, 
felsefeciler, kavramlarla ilgilenip onları analiz etmek zorundadır. Dolayısıyla başkalarına nazaran onların dil hakimiyeti ve dilin kullanımı konusundaki yargıları daha güçlüdür. Ortalama normal insanlara nisbeten onların kavramsal analiz performansları daha donanımlıdır (Gasparatou 2010: 33).

Deneysel Felsefenin ortaya çıktığg ilk günden ya da bu tarz bir felsefî̀ eğilimin dillendirilmeye başladığ günden bu yana birçok düşünürün bu felsefî hareketi eleştirdiği ilk husus yukarıda da ifadesini bulmuş olan şu husus olmuştur:Toplumsal yargılarla ilgili ampirik datalar, felsefî tartışmalar için uygun değildir. Yani toplumsal yargılar, uzman yargılara nazaran felsefî problemlerin analizinde dezavantaja sahip olduğundan felsefî̀ problemlerin ele alınmasında uzman yargılarına dayanılmalıdır. $\mathrm{Bu}$ meselenin bir diğer yönü de matematikçi, fizikçi vs. gibi bilim adamlarının kendi teorilerinin, kendileriyle benzer donanımlara sahip olmayan sıradan insanların yargılarıyla birleştirilmesine karşı çıkmalarıdır. Böyle bir eğilimden rahatsızlık duyarlar. $\mathrm{Bu}$ görüşe göre uzman bir insanın yargısı, felsefî anlamda, toplumdaki normal insanların yargılarına nisbeten daha önemli bir role sahiptir (Nadelhoffer ve Nahmias 2007: 129).

Deneysel Felsefenin yargı analizleri şunu göstermiştir: Yargılarımızın farklılığı ve birbirinden ayrı olmasına etki eden duygularımız, eğitim durumlarımız vb. gibi birçok unsur vardır. Bütün bunlara ilaveten aynı insanın aynı olaya dair farklı yargılara sahip olduğu gerçeği de aşikârdır. Farklı kültürel arka plana, farklı entelektüel alışkanlıklara ve bilgi durumlarına sahip insanların sahip olduğu yargı durumları da birbirinden farklıdır. Buradan yola çıkarak bir toplumun, kültürün parçası olarak filozofların da sahip olduğu yargıların üzerinde birleşilmiş bir varsayım, kanıt ve kural olmadığı da ortaya çıkar. Bu zikredilen düşünceler, Deneyimsel Felsefenin uzun yıllar önce tesbit edilen psiko-sosyal nedenlere dayanarak yapmış olduğu tesbitlerdir. Bu düşüncelere ilaveten sahip olduğumuz birçok kavramın, zihinsel refleksiyon sayesinde elde edildiğini görürüz. Zihinsel refleksiyonun da kavramsal analiz esnasında ampirik bilgilerimizle sahip olduğumuz birtakım inançlarımızdan bağımsız olarak gerçekleştiği söylenemez. Bu sebeple sahip olduğumuz yargılar, uylaşımsal, saf kavramsal norm ve 
durumlardan elde edilemez. Dolayısıyla yargılarımızın insanların birtakım inançları tarafından yönetiliyor olduğu gerçeğini kabul etmemiz gerekir. Ancak bu tür düşünceler Deneysel Felsefede uzun yıllar önce dillendirilmiştir. Ve bunlardan bazıları masabaşı düşünceler olarak ortaya çıkmıştır. Şöyle ki kavramsal analiz ampirik bilgi ve inançlardan bağımsız değildir. İnsanların inançları tarafından yönetilirler (Gasparatou 2010: 36).

Deneysel Felsefenin eleştirildiği bir başka husus da şudur: Bu düşünürlere göre Deneysel Felsefe ile uğraşan filozofların çalışmaları, gerçek deneyler olarak nitelenemez. Buna sebep olarak şunlar gösterilir: Temsil edilen deneysel durumlar için rastgele seçilmiş deneklerin belirlenmesinin zorluğu ve karışıklıklara yol açan değişikliklerin riskleri göz önüne alındığında ve olası rahatsız edici faktörleri kontrol etmeye yönelik alternatif stratejilerin yokluğu. Deneysel Felsefenin yapmış olduğu düşünce deneyimi senaryoları daha çok anket çalışmalarından elde edilen sonuçlara benzer. Anket çalışmaları, gözlemsel araştırmalar, arşiv çalışmaları ve olgu analizleri olmakla birlikte deneysel ya da korelasyon araştırması olmayan bir alana ait araştırmalardır. Anketlerdeki temel amaç; insanların tutumlarının, fikirlerinin toplanmasıdır. Anketlerin önemli bir işlevi ise mitleri ortadan kaldırmaktır. Bu, şöyle anlaşılmalıdır. Deneysel filozofların deklare ettikleri amaçları, felsefî yargılar üzerindeki genel bir anlaşma mitinin ortadan kaldırılmasıdır (Nicoli 2007: 143-144). Dolayısıyla Deneysel Felsefe çalışmaları anket çalışmalarının sahip olduğu dezavantajlarının tümüne sahip olduğu gerekçesiyle eleştirilmiştir.

Deneysel Felsefenin eleştirisi için ileri sürülmüş eleştirilerin hiçbirisi, gündelik yargılarımızın araştırılmasının ve Deneysel Felsefe metotlarının kullandığı kavramların felsefede bütünüyle yanlış olduğunu göstermede yetersizdir. Deneysel Felsefe bu bağlamda ortaya çıkmış eleştiri ve problemlerin yatıştırılmasında gerekli metodolojik araç ve felsefi argümanlara sahiptir. Ancak kesin olan şudur ki Deneysel Felsefe, felsefî araç olarak kullanılan gözlem ve deneyi felsefi amaç olarak kullanmak hedefinde olan bir gayrettir. Ancak böyle bir gayret felsefî amaçları 1skalar. Çünkü felsefede, bu tür nitelikler ön plana çıktığı anda felsefî alan, bilime dönüşmüş olur. 


\section{KAYNAKÇA}

ANSTEY, Peter R. ve Alberto VANZO (2016). "Early Modern Experimental Philosophy". A Companion to Experimental Philosophy. Ed. Justin Sytsma-Wesley Buckwalter. 87-102.

FİSCHER, Eugen ve John COLLINS (2015). "Rationalism and Naturalism in The Age of Experimental Philosophy". Experimental Philosophy, Rationalism, and Naturalism: Rethinking Philosophical Method. Ed. Eugen Fischer-John Collins. 3-33.

GASPARATOU, Renia (2010). "Experimental Appeals to Intuition”. CRÍTICA, Revista Hispanoamericana de Filosofía 42/124: 31-50.

GÜRSOY, Adnan (2015). İbn Sînâ'nın Sezgi Teorisi, ( Yayımlanmamış Doktora Tezi) Ankara Üniversitesi Sosyal Blimler Enstitüsü, Ankara.

HAKLI, Şaban (2007). "İbn Sînâ Epistemolojisinde Bir Bilgi Kaynağı Olarak Sezgi”, Hitit Üniversitesi İlahiyat Fakültesi Dergisi, c. 6, sayı. 11: 35-52. Yayınları.

KANT, Immanuel (1993). Arı Usun Eleştirisi, çev. Aziz Yardımlı, İstanbul: İdea

KARSLI, Ömür (2017). “Gazzali'de Sezginin Anlamı, Konumu Ve Sınır1 Sorunu”. International Journal of Social Science 62: 497-509.

KNOBE, Joshua (2016). "Experimental Philosophy Is Cognitive Science". A Companion to Experimental Philosophy. Ed. Justin Sytsma-Wesley Buckwalter:37-52, United Kingdom: John Wiley and Sons Ltd. Press.

KNOBE, Joshua ve Shaun NICHOLS (2008). "An Experimental Philosophy Manifesto". Experimental Philosophy. Ed. Joshua Knobe-Shaun Nichols: 3-14, USA: Oxford University Press.

KORNBLITH, Hilary (2015). "Naturalistic Defenses of Intuition". Experimental Philosophy, Rationalism, and Naturalism: Rethinking Philosophical Method. Ed. Eugen Fischer-John Collins. 151-168, New York: Routledge Press.

KURTAR, Senem (2011). "Sezginin Ar1 Formu ya da Formel Sezgi Olarak Kant'ta Zaman: Heidegger'i Marburg Okulu'ndan Ayıran Yitimsellik Paradoksu”. Kaygı Uludă̆ Üniversitesi Fen Edebiyat Fakültesi Felsefe Dergisi 17 (Güz): 12-29.

MACHERY, Edouard (2016). "Experimental Philosophy of Science". A Companion to Experimental Philosophy. Ed. Justin Sytsma-Wesley Buckwalter: 477490, United Kingdom: John Wiley ve Sons, Ltd. Press.

NADELHOFFER, Thomas ve Eddy NAHMIAS (2016). "The Past and Future of Experimental Philosophy”. Philosophical Explorations 10/2 (June): 123-149.

NICOLI, Serena Maria (2016). The Role of Intuitions in Philosophical Methodology, London: Palgrave Macmillan Publishers Ltd. Press. 
ÖKTEM, Ülker (2000). "Descartes, Kant, Bergson ve Husserll'de Sezgi”, A. DTCF Dergisi, 40/1-2: 159-189.

PLAKIAS, Alexandra (2015). "Experimental Philosophy”, Erişim Tarihi: 25.02.2018, Oxford Handbooks Online (February): 1-20. https://doi.org/10.1093/oxfordhb/9780199935314.013.17.

PRINZ, Jesse J (2008). "Empirical Philosophy and Experimental Philosophy". Experimental Philosophy. Ed. Joshua Knobe-Shaun Nichols. 189-208. USA: Oxford University Press.

RAWLS, John Bordley (1999). A Theory Of Justıce, Cambridge: Harvard University Press.

SOSA, Ernest (2008). "Experimental Philosophy and Philosophical Intuition" Experimental Philosophy. Ed. Joshua Knobe-Shaun Nichols: 231-240, USA: Oxford University Press.

STICH, Stephen ve Kevin P TOBIA (2016). "Experimental Philosophy and The Philosophical Tradition". A Companion to Experimental Philosophy. Ed. Justin SytsmaWesley Buckwalter: 5-21, United Kingdom: John Wiley ve Sons, Ltd. Press.

SYTSMA, Justin (2017). "Two Origin Stories for Experimental Philosophy". Teorema: International Journal of Philosophy Vol. 36/3: 23-43.

VURAL, Mehmet (2002). “Gazzâlî’nin Epistemolojisinde Sezgi ve İlham”. Tasavvuf İlmî ve Akademik Araştırmalar Dergisi 9 (January): 179-186.

WEINBERG, Jonathan M.; NICHOLS, Shaun; STICH, Stephen P (2008). "Normativity and Epistemic Intuitions". Experimental Philosophy. Ed. Joshua KnobeShaun Nichols:17-45. USA: Oxford University Press. 